\title{
APLIKASI PENGECEKAN KONDISI KESIAPAN INSTRUMENT DAN EQUIPMENT
}

(Studi Kasus: PT. SEMEN GRESIK Tbk Ds. Sember Arum Kec. Kerek Kab. Tuban)

\author{
Abdul Malik ${ }^{1}$, Siti Sufaidah ${ }^{2}$, Moh. Anshori Aris Widya ${ }^{3}$ \\ 1,2,3) Fakultas Teknologi Informasi Universitas KH. A. Wahab Hasbullah
}

Correspondence Author: chemik86@gmail.com

\begin{abstract}
In management motor and electro in PT. Semen Gresik Tbk for check condition of instrument and equipment use manual program. For detect condition it user collect many data, that make checking proses not efficient. Now Application program for check condition equipment and instrument make user require data recur that make very much data entry.

For check condition of instrument and equipment user have to complete the instrument code. After this application went execute and search the data in database of application. After the data is finds application will show the data in form in automatic on a scale. Continued, the data is process with application for detect condition of equipment and instrument in ready, no, or the status is warning.

Product from this examination is application program for check condition of instrument and equipment to PT. Semen Gresik Tbk this program give information from condition of instrument and equipment every time and this report in graph.
\end{abstract}

Keyword: Application program, Checking condition, Equipment, Instrument, Graph

\section{INTISARI}

PT. Semen Gresik Tbk pada sub bagian motor dan elektro untuk mengetahui kondisi kesiapan equipment dan instrument selama ini masih menggunakan pengecekan secara manual. Untuk mengetahui kondisi pengecekan secara berkala karyawan harus mengumpulkan data - data pengecekan yang dilakukan, Sehingga membuat proses pengecekan menjadi kurang efisien. Selain itu program aplikasi yang ada saat ini untuk melakukan sebuah pengecekan kondisi kesiapan user melakukan input data secara berulang sehingga membuat data yang dimasukan menjadi banyak.

Untuk melakukan pengecekan kondisi kesiapan instrument dan equipment pengguna cukup memasukan kode instrument. Setelah kode instrument dimasukan, aplikasi akan melakukan pencarian data yang ada didalam sebuah basis data. setelah ditemukan data akan dimunculkan secara otomatis oleh aplikasi. Selanjutnya data dapat di proses oleh aplikasi untuk mengetahui kondisi kesiapan equipment dan instrument dalam keadaan siap, tidak, ataupun dalam status peringatan.

Hasil dari penelitian ini adalah sebuah program aplikasi yang digunakan untuk melakukan pengecekan kondisi kesiapan instrument dan equipment untuk PT. Semen Gresik Tbk yang mampu memberikan laporan berupa informasi kondisi kesiapan instrument dan equipment secara berkala dalam bentuk grafik.

Kata - kunci : Program aplikasi, Pengecekan kondisi kesiapan, Equipment, instrument, Grafik 


\section{Pendahuluan}

PT. Semen Indonesia adalah sebuah perusahaan yang bergerak dalam bidang produksi semen. PT. Semen Indonesia adalah perusahaan gabungan dari. PT. Gresik (Tuban), PT. Semen Padang (Padang), dan PT. Tonasa (Papua). Dalam proses produksi jumlah semen yang dihasilkan bergantung pada mesin produksi semen. Setiap mesin mempunyai fungsi dan tugas khusus dalam proses produksi semen. Salah satu mesin yang berperan adalah Equipment dan instrument (motor) yang berada di kontrol oleh sub bagian mesin elektro. Untuk menunjang produksi semen perlu dilakukan pengecekan kesiapan Equipment dan Instrument secara berkala. Pengecekan dilakukan untuk melihat kesiapan / kondisi equipment tiap wilayah khususnya PT. Semen Gresik Tuban. Aplikasi yang digunakan untuk melakukan pengecekan equipment saat ini hanya sebatas menampilkan kondisi equipment (Ready, Warning, atau Eror). Aplikasi yang ada saat ini tidak mampu menyimpan data kesiapan equipment yang sebelumnya, sehingga pegawai kesulitan untuk melihat kesiapan equipment beberapa hari sebelumnya karena kesiapan equipment yang dicatat hanya kondisi saat ini.

Selain itu proses penginputan yang dilakukan masih terlalu rumit dengan banyaknya data yang dientrikan. Tidak hanya menginputkan nilai instrument tetapi juga menginputkan data equipment. Padahal data equipment dapat dipanggil dengan query sehingga user hanya perlu memasukan nilai instrument yang selanjutnya diproses oleh aplikasi untuk mengetahui presentase kesiapan equipment. Dengan pemanggilan data proses entry data menjadi lebih cepat dan pengecekan kesiapan equipment lebih cepat ditampilkan.

Equipment yang dimiliki oleh PT. Semen Gresik sangat banyak jumlahnya sehingga dibagi menjadi tiga wilayah. Berdasarkan latar belakang masalah tersebut dibutuhkan aplikasi pengecekan equipment yang dapat membedakan dimana wilayah equipment tersebut berada. Dengan pembagian wilayah, penanganan kesiapan equipment menjadi lebih fokus.

\subsection{Rumusan Masalah}

Berdasarkan latar belakang masalah di atas, dapat dirumuskan masalah sebagai berikut :

1. Bagaimana membuat program aplikasi pengecekan equipment yang dapat memberikan laporan data kesiapan masa lalu dan saat ini ?

2. Bagaimana membuat program aplikasi pengecekan equipment yang tidak membutuhkan banyak entry data untuk mengatahui presentasi kesiapan equipment?

\subsection{Batasan Masalah}

Program aplikasi yang dibuat hanya untuk pengecekan kesiapan equipment dan instrument yang dapat menampilkan kondisi equipment yang telah beralu dan saat ini dalam bentuk table. Serta dapat menampilkan kondisi kesiapan equipment berdasarkan wilayah.

\subsection{Tujuan Penelitian}

Berdasarkan masalah yang telah dirumuskan sebelumnya, maka tujuan penelitian ini adalah :

1. Membuat program aplikasi pengecekan equipment yang dapat memberikan laporan data kesiapan masa lalu dan saat ini.

2. Membuat program aplikasi pengecekan equipment yang tidak membutuhkan banyak entry data untuk mengatahui presentasi kesiapan equipment.

\section{Kajian Teori}

\subsection{Pokok Permasalahan}

Program aplikasi pengecekan kondisi kesiapan instrumentasi dan equipment adalah program aplikasi yang dibangun untuk memudahkan pengecekan status kesiapan instrumentasi dan equipment yang dimiliki oleh PT. Semen Indonesia Tbk (cab. Tuban). Karena kondisi kesiapan equipment dan instrumentsi mempengaruhi perawatan mesin, jika kondisi instrumentasi dan equipment dalam keadaan warning atau no (Tidak siap) perlu dilakukan perawatan untuk menanggulangi kerusakan mesin yang lebih serius.

Program aplikasi ini hanya dapat melakukan pengecekan kondisi kesiapan instrumentasi dan equipment serta menampilkan kesiapan secara periodik dalam bentuk laporan (table) dan dalam 
bentuk grafik. Laporan dalam bentuk grafik dibuat agar pengguna dapat melihat tingkat kesiapan equipment dan instrument dalam kurun waktu tertentu.

\subsection{Perangkat Lunak yang digunakan}

\subsubsection{Visual Basic.Net}

Microsoft Visual Basic .NET adalah sebuah alat untuk mengembangkan dan membangun aplikasi yang bergerak di atas sistem .NET Framework, dengan menggunakan bahasa BASIC. Bahasa Basic pada dasarnya adalah bahasa yang mudah dimengerti sehingga pemrograman di dalam bahasa Basic dapat dengan mudah dilakukan meskipun oleh orang yang baru belajar membuat program.

Hal ini lebih mudah lagi setelah hadirnya Microsoft Visual basic, yang dibangun dari ide untuk membuat bahasa yang sederhana dan mudah dalam pembuatan scriptnya (simple scripting language) untuk graphic user interface yang dikembangkan dalam sistem operasi Microsoft Windows. Visual Basic. NET ialah bahasa pemrograman event-drivent yang berasal dari BASIC event driven artinya program menunggu sampai adanya respons dari pemakai berupa kejadian tertentu, misalnya tombol diklik atau menu dipilih. Ketika event terdeteksi,event yang berhubungan akan melakukan aksi sesuai dengan kode yang diberikan. Visual Basic merupakan salah satu Development Tool yaitu alat bantu untuk membuat berbagai macam program komputer, khususnya yang menggunakan sistem operasi Windows. Di dalam pemrogramanVisual Basic ini mengadopsi dua macam jenis pemrograman yaitu Pemrograman Visual dan Object Oriented Programming (OOP)

Fitur-fitur baru dalam Visual Basic.NET ini dirancang untuk membantu Pengguna untuk mendapatkan lebih sedikit baris kode. Berikut ini fitur baru dan pengembangan dari Versi VB 6.0 sebelumnya :
A. Implisit Line Lanjutan
B. Pernyataan Lambdas
C. Auto-Diimplementasikan Properties
D. Dynamic Language Runtime
E. Generik Varians
F. Peningkatan Opsional Parameter

\subsubsection{Database MySql}

MySQL adalah sebuah implementasi dari sistem manajemen basisdata relasional (RDBMS) yang didistribusikan secara gratis dibawah lisensi GPL (General Public License). Setiap pengguna dapat secara bebas menggunakan MySQL, namun dengan batasan perangkat lunak tersebut tidak boleh dijadikan produk turunan yang bersifat komersial. MySQL sebenarnya merupakan turunan salah satu konsep utama dalam basisdata yang telah ada sebelumnya. SQL (Structured Query Language). SQL adalah sebuah konsep pengoperasian basisdata, terutama untuk pemilihan atau seleksi dan pemasukan data, yang memungkinkan pengoperasian data dikerjakan dengan mudah secara otomatis.

Kehandalan suatu sistem basisdata (DBMS) dapat diketahui dari cara kerja pengoptimasinya dalam melakukan proses perintah-perintah SQL yang dibuat oleh pengguna maupun programprogram aplikasi yang memanfaatkannya. Sebagai basis data, MySQL mendukung operasi basisdata transaksional maupun operasi basisdata non-transaksional. Pada modus operasi nontransaksional, MySQL dapat dikatakan unggul dalam hal unjuk kerja dibandingkan perangkat lunak basisdata kompetitor lainnya. Namun pada modus non-transaksional tidak ada jaminan atas reliabilitas terhadap data yang tersimpan, karenanya modus non-transaksional hanya cocok untuk jenis aplikasi yang tidak membutuhkan reliabilitas data seperti aplikasi blogging berbasis web (wordpress), CMS, dan sejenisnya. Untuk kebutuhan sistem yang ditujukan untuk bisnis sangat disarankan untuk menggunakan modus basisdata transaksional, hanya saja sebagai konsekuensinya unjuk kerja MySQL pada modus transaksional tidak secepat unjuk kerja pada modus nontransaksional. 


\section{Bahan dan Metode}

Dalam membangun sistem atau aplikasi yang baru dibutuhkan beberapa dukungan dari perangkat keras, perangkat lunak, serta informasi. Agar aplikasi yang baru dapat berjalan serta diimplementasikan dengan maksimal oleh perusahaan.

\subsection{Kebutuhan Perangkat Keras}

Perangkat keras merupakan komponen komputer dan inti dari sebuah sistem, serta penyedia sumber daya untuk keperluan komputerisasi yang digunakan.. Komponen perangkat keras yang dibutuhkan untuk mendukung program aplikasi pengecekan kondisi kesiapan equipment dan instrument pada Pt. Semen Indonesia Tbk (Pabrik Tuban) antara lain:

a. Komputer dengan prosessor $2 \mathrm{GHz}$ atau lebih tinggi.

b. VGA 32MB bit dengan resolusi $1024 \times 768$ atau lebih tinggi.

c. Memori RAM 512MB atau lebih tinggi

d. Monitor

e. Printer

\subsection{Kebutuhan Perangkat Lunak}

Secara keseluruhan, perangkat lunak membantu para pengguna untuk memanfaatkan sumber daya komputasi yang disediakan oleh perangkat keras. Dalam hal ini kebutuhan perangkat lunak untuk pengembangan aplikasi pengecekan kondisi kesiapan equipment dan instrument antara lain:

a. Sistem Operasi Microsoft Windows 7.

b. Microsoft Visual Studio 2008.

c. Xampp untuk menjalankan database MySql.

\subsection{Kebutuhan Informasi}

Laporan yang dibutuhkan oleh Pt. Semen Indonesia Tbk (Pabrik Tuban) dalam program aplikasi pengecekan kesiapan kondisi kesiapan equipment dan instrument adalah :

a. Laporan yang dapat menampilkan kondisi kesiapan instrument secara periodik.

b. Laporan yang dapat menampilkan seluruh kondisi kesiapan instrument berdasarkan wilayah.

Laporan kondisi kesiapan equipment dan instrument dalam bentuk grafik, untuk memudahkan pengecekan stabilitas secara periodik.

\subsection{Alur Sistem}

Flowchart sistem menggambarkan tentang alur kerja sistem pada program Aplikasi Pengecekan Kondisi Kesiapan Equipment dan instrument pada PT. Semen Indonesia Tbk.

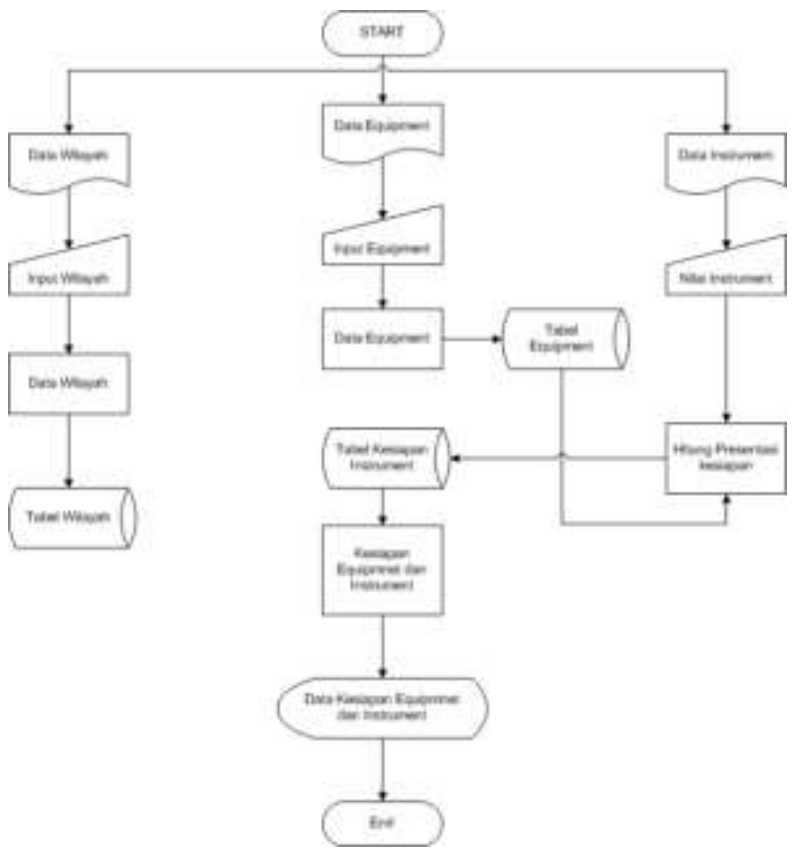

Gambar 1. Flowchart sistem program aplikasi pengecekan 


\subsection{Desain Database}

Rancangan basis data yang digunakan untuk sistem pengecekan kondisi kesiapan equipment dan instrumentasi dapat dijelaskan dengan diagram relasi antar tabel pada halaman berikut ini :

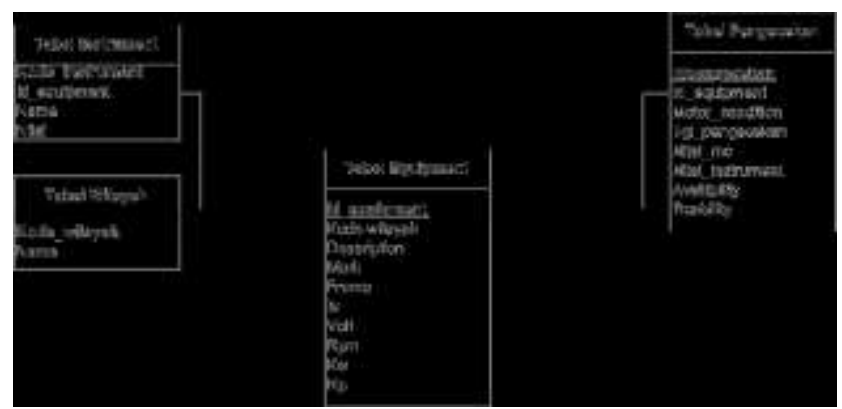

Gambar 2. Diagram relasi antar tabel

\subsection{Desain Form Pengecekan}

Pada form ini proses penghitungan kondisi kesipan equipment dan instrument dilakukan untuk kemudian hasilnya ditampilkan dalam bentuk angka presentasi (reability) dan dalam bentuk status (avaibility) : No, WARNING, READY. Berikut adalah desain dari form pengecekan

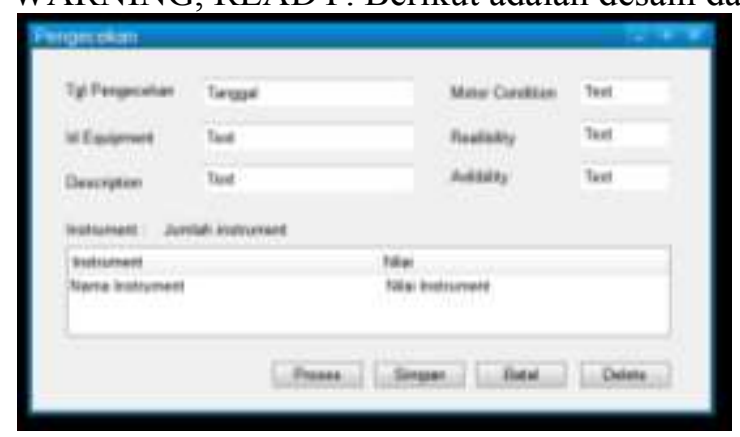

Gambar 3. Desain Form equipment

\section{Hasil dan Pembahasan}

\subsection{Pengujian Menggunakan Metode Blackbox}

Pengujian pada proses login pada aplikasi pengecekan kondisi kesiapan equipment dan instrument menggunakan metode blackbox.

Tabel 1. Pengujian Black box Pada Menu Login Admin.

\begin{tabular}{|c|c|c|c|c|}
\hline $\begin{array}{l}\text { Sekenario } \\
\text { Pengujian }\end{array}$ & Test Case & $\begin{array}{l}\text { Hasil Yang } \\
\text { diharapkan }\end{array}$ & Hasil Pengujian & Kesimpulan \\
\hline $\begin{array}{l}\text { Mengisi } \\
\text { Username dan } \\
\text { Password } \\
\text { dengan benar, } \\
\text { Klik Login }\end{array}$ & $\underset{\text { SDENIIENA }}{\stackrel{A}{E}}$ & $\begin{array}{l}\text { Sistem } \\
\text { menerima login } \\
\text { dan muncul } \\
\text { pesan login } \\
\text { sebagai admin }\end{array}$ & 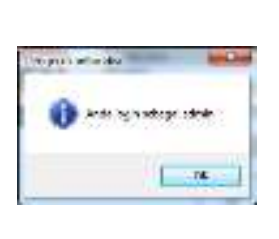 & Valid \\
\hline $\begin{array}{l}\text { Mengisi } \\
\text { Username dan } \\
\text { Password tidak } \\
\text { benar (Salah), } \\
\text { Klik Login }\end{array}$ & 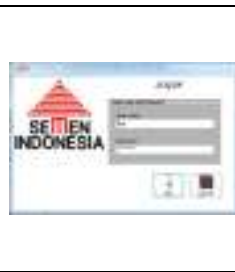 & $\begin{array}{l}\text { Sistem Akan } \\
\text { menampilkan } \\
\text { pesan " maaf } \\
\text { nama pengguna } \\
\text { atau kata kunci } \\
\text { salah" }\end{array}$ & 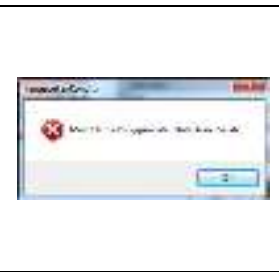 & Valid \\
\hline
\end{tabular}

ISSN Print $\quad$ : 1979-7141 
Pengujian pada proses pengecekan kondisi kesiapan equipment dan instrument pada aplikasi menggunakan metode blackbox.

Tabel 2. Pengujian Black box Pada Menu pengecekan kondisi.

\begin{tabular}{|l|c|l|l|l|}
\hline $\begin{array}{l}\text { Sekenario } \\
\text { Pengujian }\end{array}$ & Test Case & $\begin{array}{l}\text { Hasil Yang } \\
\text { diharapkan }\end{array}$ & Hasil Pengujian & Kesimpulan \\
\hline $\begin{array}{l}\text { Mengisi id } \\
\text { equipment, } \\
\text { nilai }\end{array}$ & & $\begin{array}{l}\text { Sistem } \\
\text { menampilkan } \\
\text { instrument, } \\
\text { motor } \\
\text { condition } \\
\text { dan Klik } \\
\text { proses }\end{array}$ & $\begin{array}{l}\text { motor } \\
\text { condition. } \\
\text { Reability, } \\
\text { avaibility } \\
\text { dan } \\
\text { presentase } \\
\text { kesiapan }\end{array}$ & \\
\hline
\end{tabular}

Pengujian pada proses pembuatan laporan kondisi kesiapan equipment dan instrument dalam bentuk grafik dan tabel pada aplikasi menggunakan metode blackbox.

Tabel 3 Pengujian Black box Pada Form laporan.

\begin{tabular}{|c|c|c|c|c|}
\hline $\begin{array}{l}\text { Sekenario } \\
\text { Pengujian }\end{array}$ & Test Case & $\begin{array}{l}\text { Hasil Yang } \\
\text { diharapkan }\end{array}$ & Hasil Pengujian & Kesimpulan \\
\hline $\begin{array}{l}\text { Pilih menu } \\
\text { "laporan } \\
\text { kesiapan tiap } \\
\text { equipment", } \\
\text { isikan id } \\
\text { equipment, } \\
\text { rentang } \\
\text { tanggal }\end{array}$ & 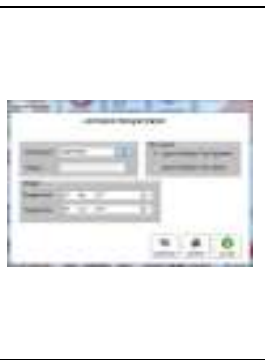 & $\begin{array}{l}\text { Sistem } \\
\text { menampilkan } \\
\text { laporan kondisi } \\
\text { kesiapan } \\
\text { equipment } \\
\text { berdasarkan id } \\
\text { equipment dan } \\
\text { rentang tanggal }\end{array}$ & $\overline{\overline{-\bar{F}}}$ & Valid \\
\hline $\begin{array}{l}\text { Pilih menu } \\
\text { "laporan } \\
\text { kesiapan tiap } \\
\text { equipment", } \\
\text { isikan id } \\
\text { equipment, } \\
\text { rentang } \\
\text { tanggal } \\
\text { pengecekan, } \\
\text { dan klik grafik }\end{array}$ & 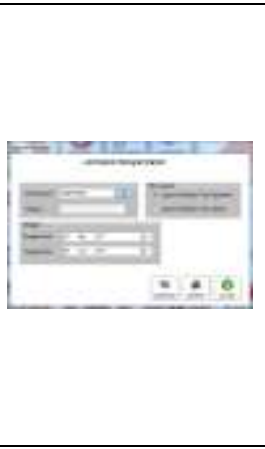 & $\begin{array}{l}\text { Sistem } \\
\text { menampilkan } \\
\text { laporan kondisi } \\
\text { kesiapan } \\
\text { equipment } \\
\text { dalam bentuk } \\
\text { grafik } \\
\text { berdasarkan id } \\
\text { equipment dan } \\
\text { rentang tanggal }\end{array}$ & $=\frac{-}{1}$ & Valid \\
\hline $\begin{array}{l}\text { Pilih menu } \\
\text { "laporan } \\
\text { kesiapan tiap } \\
\text { tiap wilayah", } \\
\text { pilih wilayah, } \\
\text { rentang } \\
\text { tanggal } \\
\text { pengecekan, } \\
\text { dan klik } \\
\text { laporan }\end{array}$ & 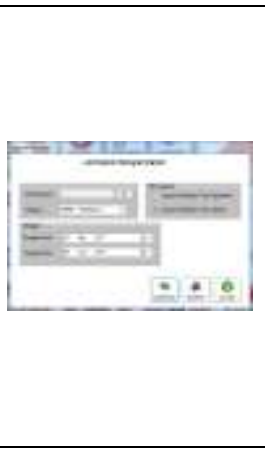 & $\begin{array}{l}\text { Sistem } \\
\text { menampilkan } \\
\text { laporan kondisi } \\
\text { kesiapan } \\
\text { equipment } \\
\text { berdasarkan } \\
\text { wilayah dan } \\
\text { rentang tanggal }\end{array}$ & 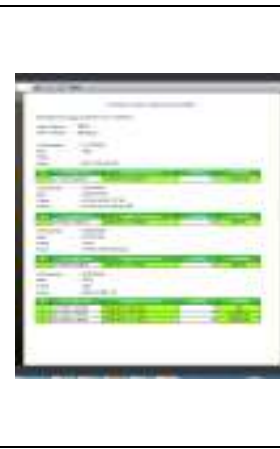 & Valid \\
\hline
\end{tabular}




\section{Kesimpulan}

Dari hasil perancangan dan pembuatan Aplikasi Pengecekan Kondisi kesiapan Equipment dan Instrument pada PT. Semen Gresik, dapat ditarik beberapa kesimpulan sebagai berikut ini:

1. Aplikasi pengecekan kondisi kesiapan equipment dan instrument yang dibuat dapat memberikan laporan secara periodik. Laporan yang disajikan dapat berupa tabel atau grafik.

2. Aplikasi pengecekan sudah terhubung kedalam database jadi tidak membutuhkan banyak entry data. Cukup memanggil data yang tersimpan dalam database yang sudah terelasi. 


\section{DAFTAR PUSTAKA}

Anonim. 1998. Kamus Besar Bahasa Indonesia. Jakarta : Pustaka Amani.

Hanif, A. 2002. Buku Analisis dan Perancangan Sistem Informasi. Yogyakarta : Andi Offset.

Hendrayudi. 2008. Visual Basic 2008 Untuk Berbagai Keperluan Pemrograman. Yogyakarta: Elex Media Komputindo.

Jogiyanto. 2005. Analisis dan Desain: Sistem Informasi Pendekatan Terstruktur Teori dan Praktek Aplikasi Bisnis. Yogyakarta : PT. Andi Offset.

Ladjamuddin. B, Al-Bahra. 2006. Rekayasa Perangkat Lunak cet-keII. Yogyakarta : GRAHA ILMU.

Ladjamudin, A. 2005. Analisis dan Desain Sistem Informasi. Yogyakarta : Graha Ilmu.

Puspitawati, L. 2011. Sistem Informasi Akuntansi. Yogyakarta: Graha Ilmu.

Santoso, H. 2010. Aplikasi Web/asp.net + cd. Jakarta : Elex Media Kompitindo.

Sitompul, D. 1994. Pengenalan Komputer dan Dasar- Dasar DOS. Jakarta : Intermasa.

Sutabri, T. 2004, Analisis Sistem Informasi. Yogyakarta : PT. Andi Offset. 